DOI:

Цяо Чжи, аспірант факультету мистецтв імені А.Авдієвського Національного педагогічного університету імені М. П. Драгоманова, м. Київ

\title{
МЕТОДИКА ФОРМУВАННЯ ЕТНОМИСТЕЦЬКОЇ КОМПЕТЕНТНОСТІ УЧНІВ У МУЗИЧНОМУ НАВЧАННІ
}

Етномистецька компетентність тлумачиться автором статті як інтегральне особистісне утворення, що є результатом етнопідготовки особистості на основі рідного фольклору та поліетнічності, спрямованої на міжетнічну художньо-творчу толерантність і повагу у ставленні людини до фольклору інших етнічних культур.

Визначено структурні компоненти феномену етномистецької компетентності - етнокогнітивний, аксіологічний, діяльнісно-творчий, мотиваційний, рефлексивний комунікативний та власне естетичний, який інтегрує решту.

Запропоновано форми та методи, які забезпечують позитивну динаміку кожного з компонентів. Розкрито поетапне застосування методики (аналітико-прогностичний, упроваджувально-змістовий, діагностувально-коригувальний етапи). Визначено методичні завдання кожного етапу.

Ключові слова: етномистецька компетентність; учнівська молодь; методика та етапи формування етномистецької компетентност; музичне навчання; поліетнічність.

Jim. 7.

Tsyao Chzhy, Postgraduate Student of Faculty of Arts named after Anatoliy Avdiyevskiy, National Mykhaylo Drahomanov Pedagogical University

\section{METHODOLOGY OF FORMATION OF ETHNO-ARTISTIC COMPETENCY OF STUDENTS IN THE PROCESS OF MUSIC EDUCATION}

The author examines the concept of ethno-artistic competence as a component of ethnocultural competence which is one of key vital competencies. The leading means of formation is determined by immersion in folklore of different types and genres. And learning music is the unifying factor.

The author considers the ethno-artistic competence to be an integral part of person that unites the aspects of ethnic preparation based on native folklore and polyethnic aspects. Polyethnicity predicts the result of interethnic artistic and creative tolerance and respect for human attitudes toward folklore of other ethnic cultures.

The structural components of the phenomenon of ethno-artistic competence are defined: the ethnocognitive, axiological, activity-creative, motivational, reflexive communicative components, as well as actually the aesthetic component, which integrates the rest.

The forms and methods of its formation, which are specified by the organization of pedagogical influence on the positive dynamics of each of the components, are offered. It is planned to implement the forms and methods in the process of musical education, which includes the lessons of artistic disciplines (musical component) and extracurricular activities of student youth.

The step-by-step application of the methodology (analytical-prognostic, introductory-informative and diagnostic-corrective stages) is revealed. The essence and methodical tasks of each stage are determined.

The content of musical education is oriented on normative documents: current educational standards, basic and standard curricula, curricula and textbooks. The emphasis is placed on the creative freedom of the teacher in choosing a musical repertoire.

Possible examples of establishing the cooperation between schools and ethnic communities reflecting the ethnic composition of Ukraine, which has developed historically, are given, as well as the examples of activities of organizations from other countries, the introduction of which the author considers expedient in the formation of ethno-artistic competence of Ukrainian schoolchildren.

Keywords: ethno-artistic competence; the student youth; the methods and stages of forming of ethnoartistic competence; music education; polyethnicity.

П остановка проблеми. У глобалізованому світі все сильнішою є тенденція до зближення культур. Водночас зростає значущість збереження кожним народом свого етнічного коріння. У процесах культурозбереження провідну роль відіграє мистецька освіта школярів, яка в кожній країні спирається на власні етнічні традиції, невід'ємні від менталітету нації, народу, кожного етносу. Опора на музичні традиції $є$ складником музичної освіти школярів різного віку, яка утворює цілісну систему, а узагальній середній освіті охоплює навчальну і позаурочну діяльність 
учнівської молоді, 3 можливістю залучення різноманітних форм позашкільного сегменту. Поряд з цим, у системі освіти актуалізується проблема інтегральності і формування в цьому контексті компетентнісної сфери особистості [3]. На часі вивчення такого феномену як етномистецька компетентність і шляхи їi формування у школярів.

Аналіз останніх досліджень і публікацій. Етномистецьку компетентність розглядаємо в контексті етнокультурної компетентності як однієї 3 ключових життєвих компетентностей особистості (Рекомендації Європейського парламенту, 18.12.2006 р.). Ці ж проблеми підкреслено нормативними освітніми документами Китаю (“Стратегія розвитку освіти в Китаї в ХХІстолітті”, “Реформи і розвиток базової освіти в КНР” та інші), культурологічними дослідженнями китайських учених [7].

Важливими для теми статті $є$ мистецтвознавчі, зокрема фольклористичні, педагогічні дослідження етноосвіти, в тому числі поли етнічний контекст, розкриття якого спирається на ідею діалогу культур (Ю. Бромлей, Г. Гачев, Сунь Гоцян, В.Дикало, Р.Осипець, А.Іваницький, Інь Хань, Лу Лу, С. Лурье, О. Хижна).

У вивченні етномистецької компетентності орієнтуємося на праці, в яких акцентується розвиток особистості, здатної до культуро творення, а компетентність у сфері культури - як одна 3 ключових, якою має оволодіти випускник школи, що входить у мультикультурний світ (Ж. Делор, С. Клепко, О. Овчарук, О. Пометун, О. Савченко, Дж. Равен, А. Хуторський).

Мета статті - обгрунтувати доцільні форми та методи формування етномистецької компетентності учнівської молоді у процесі музичного навчання.

Виклад основного матеріалу. Етномистецьку компетентність тлумачимо як інтегральний особистісний феномен, який характеризує освоєння людиною мистецьких, зокрема, фольклорних традицій власного етносу, і виявляє себе в мотивації до етномистецього пізнання у комплексі набуття знань щодо традицій, умінь практичного опанування; в дієво-ціннісному ставленні до фольклору рідного етносу, що супроводжується емоційністю його переживання, рефлексії та самооцінки; презентується у прагненні і спроможності відтворення й примноження фольклору в комунікації з іншими представниками свого етносу, а також у повазі до фольклорних традицій інших етнокультур i толерантності у комунікації з їх представниками. Отже, структуру етномистецької компетентності складають етнокогнітивний, аксіологічний, діяльнісно-творчий, мотиваційний, рефлексивний комунікативний та власне естетичний компоненти. Обрання доцільних форм та методів спрямовано на позитивну динаміку змісту кожного $з$ компонентів.

Зміст музичного навчання визначений освітнім стандартом, базовим і типовими навчальними планами та програмами [5; 6]. Однак, сучасний учитель має творчу свободу в обранні освітніх технологій, практичних завдань, оптимальних для розкриття певної навчальної теми у конкретній педагогічній ситуації, обрання художнього матеріалу для сприймання, виходячи 3 педагогічних потреб, наприклад, приналежності школи до культури певного регіону, орієнтуючись на художні якості творів, які він пропонує учням для опрацювання під час сприймання, практичнотворчого опрацювання, ілюстрування інформації про мистецькі події, явища тощо. Передбачено, зокрема, вибір мистецького матеріалу для ознайомлення з ним учнями у розв'язанні конкретної етнопедагогічної ситуації.

Логічним $є$ поетапне застосування доцільних форм і методів реалізації етномистецького змісту музичного навчання.

Завданням аналітико-прогностичного етапу є аналіз навчального матеріалу (музична та інші складники мистецької освіти), виявлення доцільних акцентів у варіативній частині навчального змісту; прогнозування, визначення дієвих способів передбачення результативності їх застосування щодо впливу на учнів; окреслення можливих дієвих заходів у позаурочний час у межах загальношкільного плану позаурочної роботи. Тобто, на цьому етапі конкретизуються можливості навчального закладу щодо формування етномистецької компетентності у навчальному сегменті та в позаурочній роботі; 3'ясовується обізнаність учителів у цій сфері діяльності, а також те, чи націлені учні на пізнання як рідних, так і інших етнічних цінностей; виявляються можливості соціокультурного оточення (репертуар концертних організацій, наявність музейних експозицій планування художніх виставок майстер-класів народних ремесел, фестивалів етнічної музики, вернісажів виробів народних ремесел, діяльність етнічних громад). Буде корисним 3'ясування того, представники яких етносів, крім українського, навчаються у школі, класі (звісно, за умови дотримання етики).

Методами цього етапу є збирання інформації щодо ставлення вчителів до планування відповідної роботи, творчі завдання для учнів та 


\section{МЕТОДИКА ФОРМУВАННЯ ЕТНОМИСТЕЦЬКОЇ КОМПЕТЕНТНОСТІ УЧНІВ У МУЗИЧНОМУ НАВЧАННІ}

виявлення проблемних питань, суперечностей, уподобань тощо 3 метою прогнозування педагогічних дій для оптимального планування навчально-виховного процесу.

Завданнями упроваджувально-змістового етапу є визначення методів і форм реалізації потенціалу музичного навчання у забезпеченні рівномірного формування всіх структурних компонентів етномистецької компетентності як цілісного феномену. Для впливу на етнокогнітивний мистецький компонент обираються методи ознайомлення учнів 3 фольклорними традиціями і цінностями рідного для учнів етносу (народні пісні, танці тощо). А саме це методи бесіди, показу, організації пошукової діяльності, порівнянь, проектів, дискусій, мистецьких передбачень, споглядання, спостереження. Форми впливу на етнокогнітивний мистецький компонент - це залучення до вербальної інтерпретації творів різних видів фольклору; пластичне інтонування музичних творів, вербального та інсценізованого пояснення термінології, ведення щоденників вражень, пояснення символіки рухів, зображень і форм декоративно-прикладного мистецтва та архітектури.

Для впливу на аксіологічний компонент обираються методи пробудження емоційності переживання художніх образів: створення установки на сприймання творів, стимулювання художньої емпатії та рефлексії; спонукання для вербального оцінювання творів (етнічних фольклорних мистецьких традицій), що дозволяє учням виявити естетичне ставлення, яке засвідчує формування мистецької цінності щодо рідного етносу та визнання цінності здобутків іншого етносу. Це можуть бути мистецькі передбачення, аналіз, зіставлення та інтерпретація творів тощо - у формах бесіди, написання есе, створення художніх образів-вражень.

Для впливу на діяльнісно-творчий компонент обираються методи занурення учнів у практичну художньо-творчу діяльність (пробудження креативності учнів і формування у них критичного мислення на основі фольклору). Дієвими формами є вправи-експериментування із засобами виразності, комп'ютерні аранжування мелодій, театралізовані експериментидемонстрації, ігри-пантоміми, творчі завдання для оптимізації вивчення і виконання вивчених пісень, танцювальних рухів, створення виробів декоративно-прикладного мистецтва як атрибутів для виконання пісень, танців, колективні мистецькі міні-проекти; прогулянки-екскурсії, евристичні завдання-перенесення персонажів пісень, танців, атрибутів в інші етнічні ситуації.

Для впливу на мотиваційний компонент обираються методи, які забезпечують позитивну налаштованість учнів на здобуття знань про фольклорні традиції різного та інших етносів, їхне зіставлення, формування уявлень школярів про спільне і відмінне; стимулювання інтересу до практичного освоєння фольклору різного та інших етносів (інтерактивно-ігрового збагачення уявлень, створення емоційно-позитивної атмосфери зустрічей $з$ мистецтвом, емоційного занурення у різні види фольклору, спонукання до самовираження й підтримки творчих результатів), які будуть результативними за умови застосування адекватних форм: участь у діалогічно-ігрових ситуаціях, створення ситуацій рольової гри, розв’язування “конфліктів”, дискусії, театралізації; міні концерти, добір і використання атрибутів, створення ескізів атрибутів, костюмів, складання сценаріїв, створення мультимедійних презентацій, прес-конференції тощо.

Для впливу на рефлексивний компонент визначаються методи, які забезпечують розвиток здатності учнів об'єктивно оцінювати своє ставлення до фольклору рідної та інших етнокультур, виокремлювати своє ставлення до різних складників мистецьких фольклорних традицій і творів - музичного, танцювального, театрального, декоративно-прикладного, оцінювати міру освоєння ним самим фольклору та об'єктивність власної оцінки. Це, передусім, методи вербального висловлювання, спонукання до саморефлексії, презентації вражень. Відповідними цим методам формами $є$ усні обговорення, написання творів, презентації творчих проектів.

Для впливу на комунікативний компонент визначаються методи, що спонукають до мистецького і міжособистісного діалогу в колективних справах, спрямовані на виховання толерантності, взаєморозуміння, взаємоповаги у процесі пізнання фольклору, зокрема, це колективні творчі завдання, мозковий штурм. Відповідні форми - мистецькі проекти, дискусії, прес конференції, ігрові ситуації, рольові ігри, лист незнайомому другу, а публічні презентації своїх ідей, здобутків тощо.

Оскільки естетичний компонент етномистецької компетентності є об’єднувальним для решти компонентів, остільки для впливу на нього необхідно визначити такий само інтегральний метод та відповідні форми. Таким є метод режисури уроку [4], що передбачає алгоритм: моделювання ситуації пізнавальної провокації; 
пояснення завдань уроку із застосуванням інтерактивних прийомів залучення учнів до планування дій з їх вирішення; встановлення балансу індивідуальних і колективних форм спілкування учнів у пізнавальному процесі - під час організації сприймання та інтерпретації творів, виконання практично-творчих пошукових завдань, осмислення результатів; організація пролонгованої підтримки - вчителем i однолітками - індивідуального творчого самовираження у процесі освоєння різних видів фольклору рідного а інших етносів; причому “індивідуальне” характеризує унікальність кожного учня незалежно від того, чи виконує він самостійно певне творче завдання, чи співпрацює 3 іншими; йдеться про повагу і підтримку творчого самовираження в обох випадках; демонстрація творчих досягнень учнями із рефлексією пізнаного, а також саморефлексією як осмисленням здобутків і недоліків, планування результатів.

Усі методи і форми можуть застосовуватися у різних видах уроків мистецтва - уроківтеатралізацій, уроків-концертів, уроків-виставок, уроків-театралізованих вистав, уроків-екскурсій, уроків-віртуальних подорожей тощо.

Формами позаурочної діяльності учнів $\epsilon$ різноманітні заходи двох типів: безпосередньо мистецького змісту і такі, що не стосуються безпосередньо мистецької творчості.

До позаурочних заходів мистецького змісту належать відвідування театрів, концертів, екскурсії, підготовка та участь у фольклорних святах, мистецьких конкурсах (наприклад, на краще виконання народної пісні, народної пісні іншого етносу), у театралізованих сценічних дійствах, проведення міні-фестивалів інсценізованих фольклорних дійств, що охоплюють усі види фольклору, підготовка бесід для учнів, підготовка і проведення бесід учнями для однолітків, літературно-музичні, музичнохореографічні композиції тощо. До позаурочних поза мистецьких заходів, належать усі заходи, в яких доцільно використовувати фольклорний мистецький матеріал - для оформлення сцени, у використанні атрибутів, реквізиту, костюмів, у музичному супроводі, елементах танців або обрядових дійств, літературних творів, що ілюструють ідею заходу, емоційно забарвлюють розгортання сценарію тощо. Такими заходами немистецького змісту можуть бути різноманітні інтелектуальні олімпіади, клуби КВК, спортивні змагання, зустрічі з цікавими особистостями, інші заходи, що відбуваються згідно із планом роботи навчального закладу.
Особливу увагу варто приділити співпраці 3 етнічними громадами, які проводять пошукову роботу зі збирання й вивчення фольклору свого етносу [1]. У більшості 3 них поглиблено вивчаються народні пісні, танці, усна народна творчість, обряди, ремесла; влаштовуються виставки і фестивалі, причому всеукраїнського та міжнародного рівня.

В Україні нині створено й осередок китайського земляцтва. Крім Києва, центри китайської культури, представництва філії асоціації традицій і культури Китаю “Чжен Гунфу” відкрито на Харківщині, Одещині, Вінничині, Черкащині, де учнівська молодь має можливість ознайомитися 3 особливостями китайського мистецтва кераміки, традиційними техніками ліплення, технологіями опалу, декору, глазурування й розпису; вивчаються легенди, міфологія Китаю. Центрами китайської культури в Україні, часто у співдружності з українськими митцями, створюються мистецькі програми і влаштовуються культурні проекти за участю китайських музикантів [2].

Крім цього, в Україні $є$ культурні центри інших країн при Посольствах і дипломатичних місіях (Французький культурний центр, Польський інститут, Інститут Гете, Україно-замбійський культурний центр, Ізраїльский культурноінформаційний центр, Центр іспанської мови і культури та інші).

Третій етап упровадження методики формування етномистецької компетентності $€$ діагностувально-коригувальним. На цьому етапі здійснюється зріз сформованості етномистецької компетентності учнівської молоді за спеціальновизначеними критеріями та показниками; визначаються подальші педагогічні дії у єдності уроку і позаурочної музичної діяльності учнів (етап наступного планування коригувальних дій). На цьому етапі застосовуються діагностувальні методики, обробляються результати пролонгованих педагогічних спостережень; для висновків використовуються продукти учнівської творчості, здійснюється їх аналіз.

Висновки і перспективи. Перпективним в етномистецькій підготовці школярів $\epsilon$ розроблення педагогічних механізмів доцільного поєднання пізнання мистецтва рідного етносу та інших етносів, які складають єдину культуру України, а також пізнання інших етнокультур світу.

\section{ЛІТЕРАТУРА}

1. Дикало B.I. Музичне краєзнавство Рівненщини як навчальний курс: до постановки 


\section{МЕТОДИКА ФОРМУВАННЯ ЕТНОМИСТЕЦЬКОЇ КОМПЕТЕНТНОСТІ УЧНІВ У МУЗИЧНОМУ НАВЧАННІ}

проблеми / В. Дикало // Нова педагогічна думка. - 2016. - № 2. - С. 124- 128.

2. Комаровська О.А., Цяо Чжи. Китайські народні традиції в музичному навчанні українських школярів / О.А.Комаровська, Цяо Чжи // Мистецтво та освіта. - 2017. - № 4. - С. 6- 10.

3. Компетентнісний підхід у сучасній освіті: світовий досвід та українські перспективи: Бібліотека з освітньої політики / За заг. ред. О.В.Овчарук. - К.: “К.І.С.”, 2004. - 112 с.

4. Мінасян Н. Г. Драматургія уроку художньої культури / Н.Г. Мінасян // Мистецтво та освіта. 2010. - № 1. - С. 54- 59.

5. Навчальна програма "Мистецтво" для 1011 класів [Електронний ресурс]. - Режим доступу: https://mon.gov.ua/ua/osvita/zagalna-serednya-osvita/ navchalni-programi/navchalni-programi-dlya-10-11klasiv.

6. Нова українська школа: основи Стандарту освіти.- Львів, 2016. - 64 с.

7. Jin, W. EnglishLanguageTeachinginCrossCulturalContexts / W. Jin // CELEA. - 2004. - Vol. 27, №1. - P. 55-58

\section{REFERENCES}

1. Dykalo,V. (2016). Muzychne kraieznavstvo Rivnenschyny yak navchalnyi kurs: do postanovky problemy [Music regional studies of Rivne as training course: the formulation of the problem]. New pedagogical thought, no, 2. pp.124-128. [in Ukrainian].

2. Komarovska, O. \& Tsiao Chzhi (2017). Kytaiski narodni tradytsii $\mathrm{v}$ muzychnomu navchanni ukrainskykh shkoliariv [Chinese folk traditions in musical education of Ukrainian schoolchildren]. Art and education, no. 4, pp. 6 - 10. [in Ukrainian].

3. Ovcharuk, O. (Ed.). (2004). Kompetentisnyi pidkhid u suchasnii osviti: svitovyi dosvid ta ukrainski perspektyvy: Biblioteka z osvitnioi polityky [Competence approach in modern education: world experience and ukrainian perspectives: Library for Educational Policy]. Kyiv, "K.I.S.”112 p. [in Ukrainian].

4. Minasian, N. (2010). Dramaturgiia uroku khudozhnioi kultury [Dramaturgy of lesson of artistic culture]. Art and education, no. 1, pp. 54-59. [in Ukrainian].

5. Navchalna programa "Mystetstvo" dla 10-11 klasiv [Studies program "Art" for 10 - 11 classes]. [Electronic recource]. Available at: https://mon.gov.ua/ ua/osvita/zagalna-serednya-osvita/navchalni-programi/ navchalni-programi-dlya-10-11-klasiv [in Ukrainian].

6. Nova ukrainska shkola: osnovy Standartu osvity (2016). [New Ukrainian school: basics of educational Standard]. Lviv, 64 p. [in Ukrainian].

7. Jin, W. (2004). English Language Teaching in Cross-Cultural Contexts. CELEA. Vol. 27, no.1, pp. 55-58. [in English].

Стаття надійшла до редакції 26.03.2018

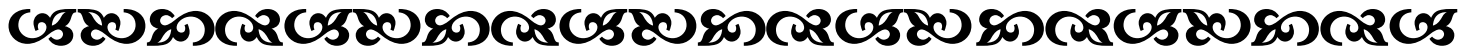

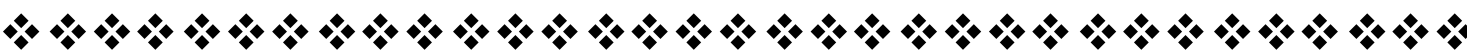

“Жодне бажання не дається тобі оқремо від сили, що дозволяє його здійснити”.

Річард Deйвіс Бах америқансьқий письменник

"Мистеитво навчання є мистецтво пробуджувати в юних душах допитливість $i$ потім задовольняти ї̈".

Анатоль Франс французький прозаїк

"ТТри риси роблять з людини диво - $і$ ще вищі дари Верховної Шूедроти: плідний талант, глибоқий розум, витончений $і$ щасливий смак". 